\title{
Ovarian teratoma in a woodchuck (Marmota monax) with hepatocellular carcinoma: radiologic and pathologic features
}

Johnathan Zeng ${ }^{1}$, Matthew F. Starost ${ }^{2}$, Michal Mauda-Havakuk', Andrew S. Mikhail', Ari Partanen', Bradford J. Wood ${ }^{3}$, John W. Karanian ${ }^{1}$ and William F. Pritchard ${ }^{1 *}$ (i)

\begin{abstract}
Background: Teratomas are germ cell neoplasms composed of a wide variety of tissues. In the woodchuck, only one testicular teratoma has been described in the literature. The objective of this report was to describe the radiologic and pathologic findings in a female woodchuck (Marmota monax) with an ovarian teratoma consisting of mature tissues originating from all three germ layers.

Case presentation: A 2-year-old female woodchuck that had been infected at birth with woodchuck hepatitis virus and subsequently developed hepatocellular carcinoma was incidentally discovered to have a mobile $6.6 \times 4.8 \times 4.7$ $\mathrm{cm}$ abdominal mass on computed tomography (CT) imaging. The tumor was predominantly solid and heterogenous on CT with soft tissue, fat, and areas of dense calcification. The teratoma did not enhance with intravenous contrast administration. On ultrasound, the tumor was solid with heterogeneous echogenicity, reflecting the fat content and areas of calcification. Sonolucent areas were present that may have represented cysts. There was heterogeneously increased signal on T1-weighted magnetic resonance imaging (MRI) and heterogeneous hyperintensity in T2-weighted imaging. Fat was evident within the tumor. At necropsy, the tumor was attached to the distal end of the right uterine horn. Histopathology showed mature tissue types representing all three germ layers.
\end{abstract}

Conclusions: Ovarian teratoma should be considered in the differential diagnosis of ovarian or abdominal masses in woodchucks. The tumor displayed mature tissue derived from all three germ layers. CT, ultrasound, and MRI findings were presented in detail and matched the typical imaging appearance of teratomas.

Keywords: Marmota, Teratoma, Ovarian neoplasm, Woodchuck, Pathology

\footnotetext{
* Correspondence: william.pritchard@nih.gov

${ }^{1}$ Center for Interventional Oncology, Radiology and Imaging Sciences,

Clinical Center, National Institutes of Health, 10 Center Drive, Room 3N320,

MSC 1182, Bethesda, MD 20892, USA

Full list of author information is available at the end of the article
}

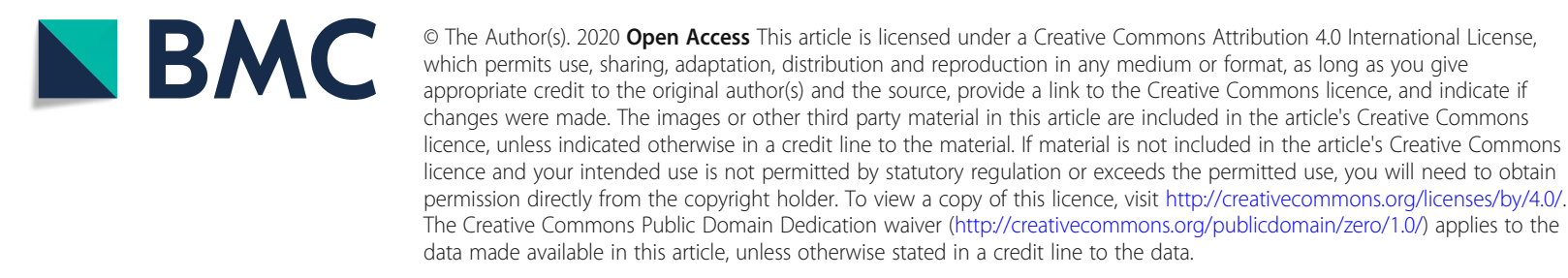




\section{Background}

There are three main types of ovarian tumors in mammals: epithelial tumors, stromal or sex cord tumors, and germ cell tumors [1]. Epithelial tumors, which include adenomas and adenocarcinomas, are the most common ovarian neoplasms. These tumors are derived from epithelium lining the ovary, including the fallopian tube and endometrium. Sex cord tumors resemble the sex cord stromal tissue of the ovary and include granulosa cell tumors, Leydig cell tumors of the ovary, and thecomas. Finally, germ cell tumors, which include teratomas and dysgerminomas, are neoplasms that mimic tissues produced by germ cells.

Teratomas are germ cell tumors with tissue derived from two or three germ layers: ectoderm, mesoderm, and endoderm. Teratomas can be immature or mature depending on the level of differentiation of each germ layer. Immature teratomas are less common and can be malignant. Mature teratomas, which are generally benign, often present with a variety of organ elements, including hair follicles, hyaline cartilage, and adipose tissue. Most often these neoplasms arise in the ovary but can also arise in the testis [1].

There have been reports of teratoma in multiple laboratory or domesticated animal species, including mice, rabbits, dogs, cats, and ferrets [2-5]. Multiple tumors have been described in the woodchuck, including lymphoma, lymphosarcoma, leiomyosarcoma, fibrosarcoma, osteosarcoma, malignant pleural mesothelioma, and meningioma [6-12]. Foley et al. reported on abnormalities in the reproductive tracts of 14 woodchucks from a series of 748 necropsies. Neoplastic lesions that were identified were uterine leiomyoma and several tumor types in the male: adenoma of the rete testis, interstitial cell tumor, seminoma, Sertoli cell tumor, lymphosarcoma, and a single case of concurrent seminoma and testicular teratoma $[13,14]$.

Eastern woodchucks (Marmota monax) infected with woodchuck hepatitis virus (WHV) have proven to be valuable pre-clinical models for the study of hepatitis B virus infection and the safety and efficacy of antiviral therapies $[15,16]$. Furthermore, since hepatocellular carcinoma (HCC) naturally develops with chronic WHV infection, woodchucks are a useful model to evaluate therapies intended to treat hepatitis-induced tumors in humans [17-19]. This report describes the first case of a female woodchuck with an ovarian teratoma and presents the diagnostic imaging and pathologic findings.

\section{Case presentation}

This study was conducted under an animal use protocol approved by the Institutional Animal Care and Use Committee in compliance with the U.S. Animal Welfare Regulations. A 2-year-old, $3.1 \mathrm{~kg}$, captive-born female woodchuck (Northeastern Wildlife, Harrison, Idaho, USA) had been infected during the first week of life with WHV (cWHV7P2a inoculum, approximately $10^{9}$ viral particles, administered subcutaneously [20]) and subsequently developed HCC prior to acquisition for the study of HCC therapies. The animal was individually housed in the institution's veterinary facility with $12-\mathrm{h}$ light:dark cycling, provided with enrichment, and given ad libitum access to food and water.

Non-invasive diagnostic medical imaging was performed using clinical systems with the animal under general anesthesia. The animal was sedated using 5\% isoflurane delivered via an induction chamber followed by a mixture of pre-anesthetics $(28.6 \mathrm{mg} / \mathrm{kg}$ ketamine $\mathrm{HCl}$ and $5 \mathrm{mg} / \mathrm{kg}$ xylazine IM) and then maintained on $1-5 \%$ isoflurane and $100 \%$ oxygen $(2 \mathrm{~L} / \mathrm{min})$ delivered via rabbit mask for the duration of the procedure. For computed tomography (CT), a $21 \mathrm{G}$ or $23 \mathrm{G}$ angiocather was inserted into a foreleg vein. At the conclusion of the planned experiments, the woodchuck was euthanized by administration of a combination of pentobarbital sodium $390 \mathrm{mg} / \mathrm{mL}$ and phenytoin sodium $50 \mathrm{mg} / \mathrm{mL}$ (Euthasol $1 \mathrm{~mL} / 10 \mathrm{lb}$;; Virbac Animal Health, Fort Worth, TX, USA). The tumor was then resected and sectioned for pathology.

For CT imaging (Philips Brilliance MX8000 IDT 16section Detector CT; Philips, Andover, MA, USA) an initial planning scan was acquired. Following non-contrast $\mathrm{CT}$ of the chest and abdomen, multiphase imaging of the abdomen was performed with power injection (Medrad Stellant CT Injection System, Bayer Healthcare, Leverkusen, Germany) of $3.0 \mathrm{~mL}$ of iopamidol i.v. (Isovue-370, Bracco Diagnostics, Monroe Township, NJ) followed by $3.0 \mathrm{~mL} 0.9 \%$ saline, all at $0.2 \mathrm{~mL} / \mathrm{sec}$. The imaging protocol was initiated once contrast appeared in the distal thoracic aorta with early arterial ( $4 \mathrm{~s}$ delay), late arterial (23 s delay), portal venous ( $43 \mathrm{~s}$ delay), and late parenchymal (63s) phases. Scans were obtained at $120 \mathrm{kVp}$ and a tube current of $225 \mathrm{~mA}$ with a $180 \mathrm{~mm}$ field of view and image reconstruction of $0.8 \mathrm{~mm}$ sections at $0.4 \mathrm{~mm}$ intervals $[19,21]$. CT imaging was performed twice, 5 weeks apart. The initial CT scan was performed to define the anatomy and the extent of hepatic disease for experimental planning. The second was acquired 2 days prior to the terminal study for the purpose of designing and 3D printing a liver-specific cutting mold for the hepatic tumors [21]. Tumor measurements and image analysis were performed using OsiriX (version 11, Pixmeo, Geneva, Switzerland).

Ultrasound imaging was performed with a phased array ultrasound probe (Philips iU22, Philips Healthcare Solutions, Bothell, WA) operating at 3.75 or $5.0 \mathrm{MHz}$. Grayscale and color Doppler sonography were performed.

Magnetic resonance imaging (MRI) was performed (Achieva $3.0 \mathrm{~T}$, Philips, Best, the Netherlands) with a 
standard 32-ch cardiac RF receive coil. MR images were acquired in the axial plane using four sequences: T1-weighted High-Resolution Isotropic Volume Examination (THRIVE), diffusion-weighted imaging (DWI), T2-weighted Turbo Spin Echo (TSE), and T2-weighted Volume Isotropic Turbo Spin Echo Acquisition (VISTA). These pulse sequences were selected to represent typical sequences used in clinical MRI liver examinations, both with and without fat suppression [21].

The scout images for the two CT examinations, separated by 5 weeks, showed a large calcified mass that was initially in the left abdomen measured as $5.7 \times 3.5 \mathrm{~cm}$
(Fig. 1a) and subsequently in the right abdomen measured as $6.5 \times 3.8 \mathrm{~cm}$ (Fig. 1b). On CT examination, the teratoma measured $6.6 \times 4.8 \times 4.7 \mathrm{~cm}$ and was well-circumscribed, predominantly solid, and heterogenous with soft tissue, fat, and areas of dense calcification (Fig. 1c, d). No fatfluid levels were identified. Two HCCs were present, one with heterogenous enhancement and necrotic regions. Unlike the enhancement of the HCC after contrast administration, the teratoma did not enhance. The right uterine horn could be traced from the body of the uterus to the mass while the left uterine horn was coiled in the caudal abdomen and pelvis. On ultrasound, the tumor was solid
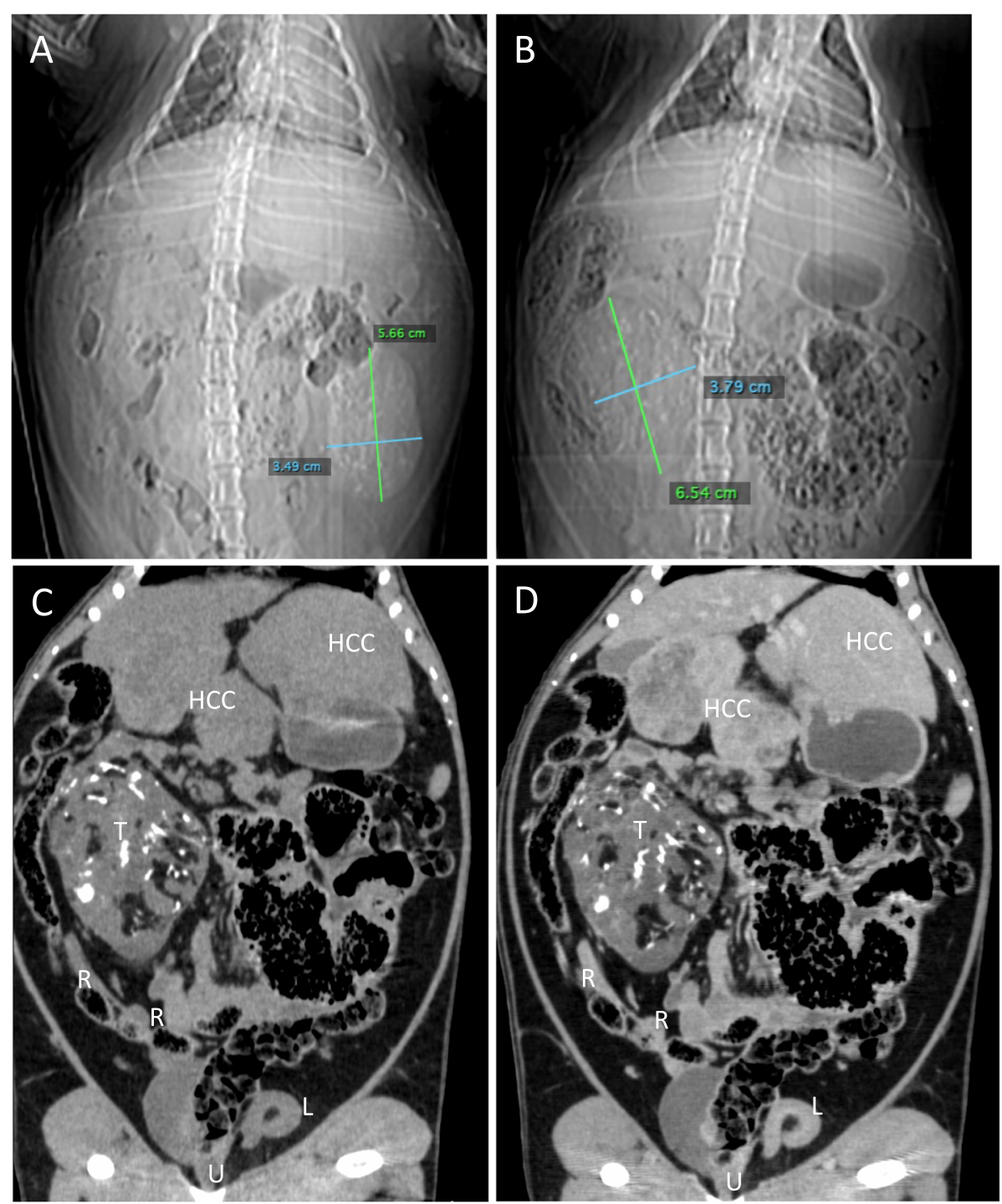

Fig. 1 Computed Tomography. a Initial CT scout image and $\mathbf{b}$ CT scout image five weeks later showed a large mass with calcifications in the left abdomen on the initial scan and in the right abdomen five weeks later. Coronal reconstructions of $\mathbf{c}$ non-contrast scan and $\mathbf{d} 1$-min delayed scan after contrast show the teratoma ( $T$ ) as predominantly soft tissue density with areas of fat and dense calcification. The right uterine horn (R) is partially shown but could be traced from the body of the uterus $(U)$ to the teratoma while the left uterine horn $(\mathrm{L})$ is coiled in the caudal abdomen or pelvis. Two hepatocellular carcinomas (HCC) are shown: a $5.8 \mathrm{~cm} \mathrm{HCC} \mathrm{in} \mathrm{the} \mathrm{left} \mathrm{medial} \mathrm{lobe} \mathrm{with} \mathrm{heterogenous} \mathrm{enhancement} \mathrm{and}$ necrotic regions on this delayed image and a $3.3 \mathrm{~cm}$ HCC in the left lateral lobe 
with heterogeneous echogenicity, reflecting the fat content and areas of calcification with acoustic shadowing. Sonolucent areas were present that may have represented cysts. There was little vascularity on color Doppler imaging (Fig. 2). On T1-weighted THRIVE MRI, there was heterogeneously increased signal with areas of signal void representing fat. DWI showed some regions with increased signal. T2-weighted TSE indicated heterogenous hyperintensity while T2-weighted VISTA showed heterogeneous low signal intensity (Fig. 3).

On gross examination following euthanasia, the teratoma was attached to the right uterine horn and was well demarcated, surrounded by a membranous translucent capsule (Fig. 4a). The HCCs were readily apparent. Histologic sections from formalin-fixed paraffin-embedded tissue samples were stained with hematoxylin and eosin. Histopathologic examination of the ovarian mass revealed tissues representing a mixture of all three germ layers: ectoderm, mesoderm, and endoderm (Table 1). Tissues from the germ layers were haphazardly arranged, although each individual tissue type could be clearly identified (Fig. 4b). Ectodermal (mesenchymal) tissue consisted of two main tissue types: neural tissue composed of neurons, glial cells, and axons; and skin with hair follicles and sebaceous glands (Fig. 4b, c). Five types of mesodermal tissue types were present: smooth muscle cells, cartilage, bone, collagen, and adipose (Fig. 4b). Mature hyaline cartilage was observed with chondrocytes interspersed within intercellular matrix adjacent to a layer of ciliated respiratory epithelium (Fig. 4d). Mature bone matrix was composed of osteocytes and contained marrow elements (Fig. 4e). Adipose tissue was seen throughout the tumor including adjacent to bone matrix and keratinized stratified squamous epithelium. Tissue of endodermal origin was present, including acinar glands and ducts. Multiple types of epithelium were present including squamous and columnar epithelium with pseudocolumnar cells lining cysts (Fig. 4b, d, f).

\section{Discussion and conclusions}

In humans, there has been variable diagnostic accuracy for teratomas among the different modalities of CT, MRI, and ultrasound. Buy et al. reported a series of cystic teratomas of the ovary and concluded that CT was the optimal diagnostic procedure [22]. They observed that fat was the most common finding in the series and argued that fat within an ovarian tumor is specific for the diagnosis. Other CT findings included Rokitansky protuberance, tooth or calcification, tufts of hair, and fat-fluid levels. In their series, $32 \%$ of the tumors were predominantly solid masses on ultrasound, as in this case. Echogenic foci with acoustic shadowing were observed. High signal intensity was observed on T1- and T2-weighted MR images in three patients. Similarly, Quillen et al. found that fat, calcifications, and low attenuation areas were the most common findings of benign cystic teratoma on CT, but could be seen uncommonly in malignant teratoma. Immature teratomas, which can demonstrate malignant characteristics, are much less common than mature teratomas [23, 24].

There is sparse reporting of clinical imaging of teratomas in small animals. The reported testicular teratoma in a woodchuck was composed of tissue derived from ectodermal and mesodermal origins partially surrounded by a seminoma. No imaging was performed [13]. While teratomas occur spontaneously in mice or rats with specific genetic mutations [25-27], imaging of teratomas has become useful in experimental studies of stem cell therapies. Riegler et al. [28] described cardiac ultrasound and MRI following transplant of human-induced pluripotent stem cells into areas of experimental myocardial infarction in rats. The utility of ultrasound was limited, but the teratomas were hyperintense on T2-weighted MRI, as in this animal. A report of imaging of a guinea pig with a palpable mass showed a $3 \mathrm{~cm}$ mass dorsal to the cecum with calcifications on an abdominal radiograph and irregular hyperechoic, hypoechoic, and anechoic
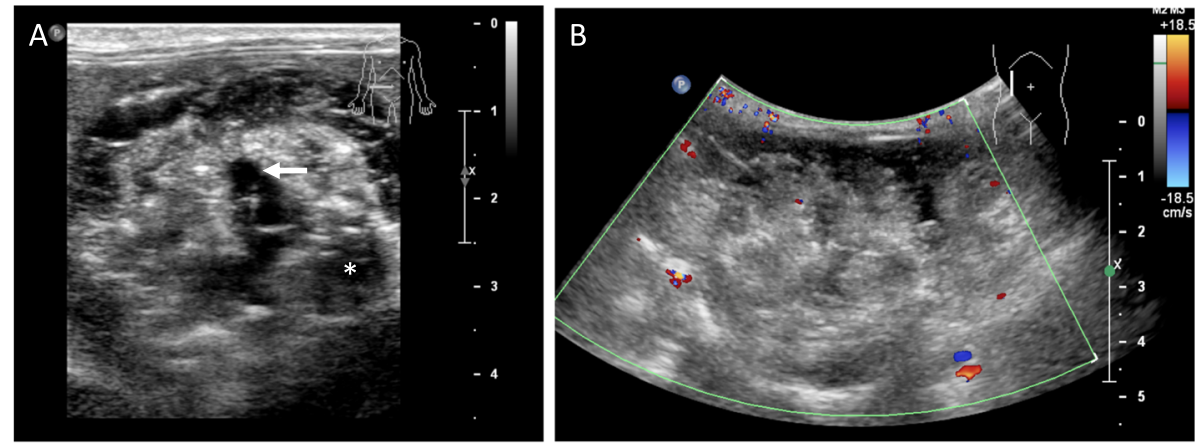

Fig. 2 Ultrasound. a Grayscale ultrasound. The teratoma was solid with heterogeneous echogenicity, reflecting the fat content and areas of calcification with acoustic shadowing (asterisk) observed. Anechoic areas were present that may have represented cysts (arrow). b. Color Doppler ultrasound. There was little vascularity on color Doppler imaging 

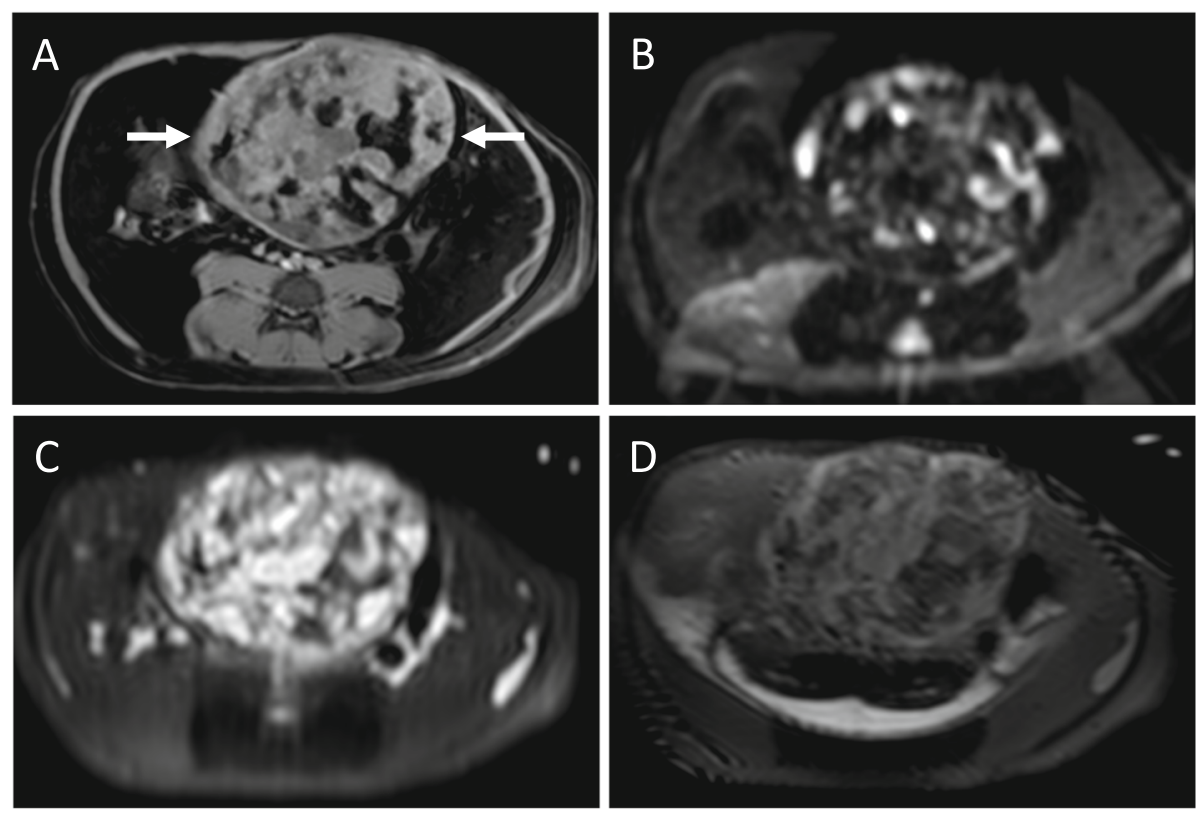

Fig. 3 Magnetic Resonance Imaging. a THRIVE image of the teratoma (arrows) with heterogeneously increased signal. Signal voids in the teratoma represent fat on this fat-suppressed imaging sequence. b Diffusion-weighted image with focal areas of increased signal. c T2-weighted TSE image with heterogeneous hyperintensity. $\mathbf{d}$ T2-weighted VISTA image with heterogeneous low signal intensity

patterns with a cystic appearance of the teratoma on ultrasound [29]. Ovarian teratomas are uncommon in cats and dogs. Mineralization within an abdominal mass on an abdominal radiograph has been reported in a teratoma in a cat [30]. Teratomas with calcification identified on abdominal radiographs or ultrasound have been reported in dogs [31-34]. Headley et al. further described the ultrasound appearance of a $22 \mathrm{~cm}$ teratoma in a German shepherd as a rounded, heterogenous, cystic, and echogenic mass [35]. In contrast, Gorman et al. reported an emaciated German shepherd with ascites and metastatic malignant teratoma in which the ultrasound examination also
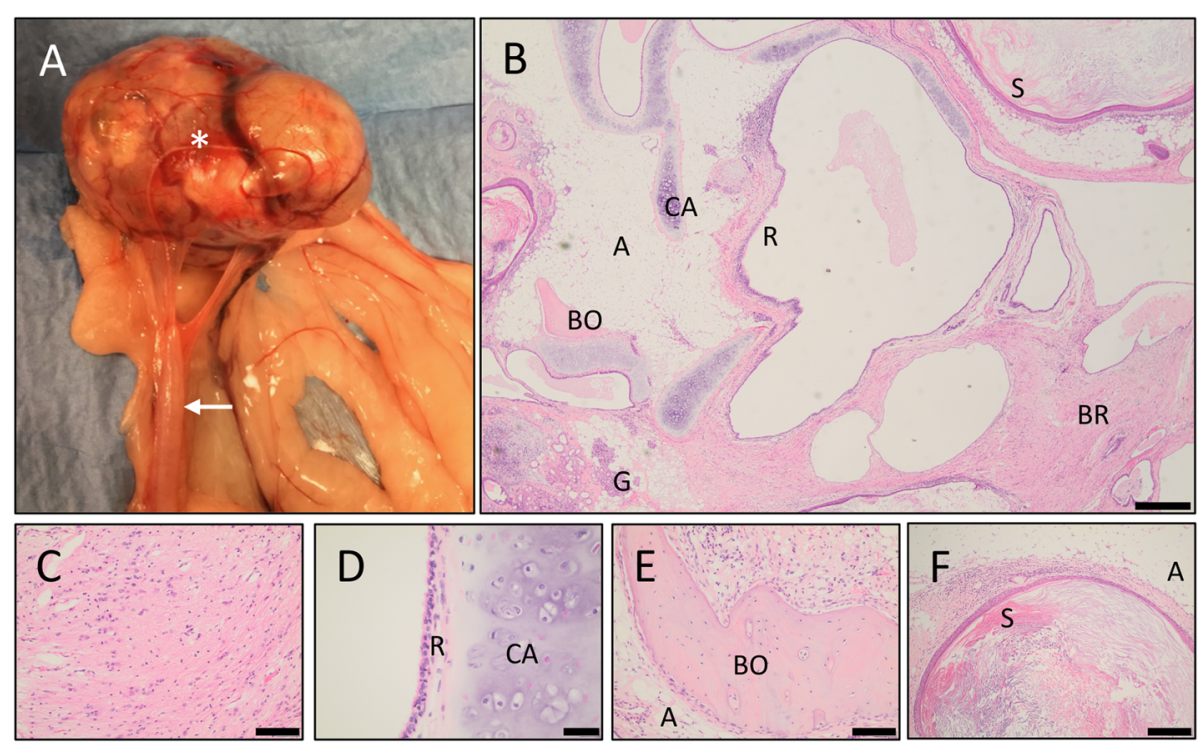

Fig. 4 Teratoma Pathology, Gross and H\&E Stains. a Gross specimen showing the teratoma (asterisk) attached to the uterine horn (arrow). b Low magnification histopathology section with multiple cell types, including brain (BR), bone (BO), cartilage (CA), white adipose tissue (A), acinar glands (G), respiratory simple columnar ciliated epithelium (R), and stratified keratinizing squamous epithelium (S). Scale bar represents $500 \mu \mathrm{m}$. c Neural tissue. Scale bar represents $100 \mu \mathrm{m}$. d Cartilage and ciliated respiratory epithelium. Scale bar represents $40 \mu \mathrm{m}$. e Mature bone matrix with adjacent adipose tissue. Scale bar represents $100 \mu \mathrm{m}$. f Keratinized stratified squamous epithelium and adipose tissue. Scale bar represents $200 \mu \mathrm{m}$ 
Table 1 Tissues within the teratoma grouped by germ layer of origin

\begin{tabular}{|c|c|c|c|}
\hline Germ Layer & Tissue & Description & Figure \\
\hline \multirow[t]{2}{*}{ Ectoderm } & Neural & Brain (CNS) & $4 \mathrm{~B}, 4 \mathrm{C}$ \\
\hline & Skin & Hair follicles, sebaceous glands & \\
\hline $\begin{array}{l}\text { Ectoderm or } \\
\text { Endoderm }\end{array}$ & Cysts & $\begin{array}{l}\text { Stratified keratinizing squamous } \\
\text { epithelium }\end{array}$ & $4 \mathrm{~B}, 4 \mathrm{~F}$ \\
\hline \multirow[t]{5}{*}{ Mesoderm } & Muscle & Smooth muscle cell bundles & \\
\hline & Cartilage & Hyaline & $4 \mathrm{~B}, 4 \mathrm{D}$ \\
\hline & Bone & Included marrow elements & $4 \mathrm{~B}, 4 \mathrm{E}$ \\
\hline & Collagen & Included fibroblasts & \\
\hline & Fat & White adipose tissue & $\begin{array}{l}4 \mathrm{~B}, 4 \mathrm{E}_{1} \\
4 \mathrm{~F}\end{array}$ \\
\hline \multirow[t]{4}{*}{ Endoderm } & Cysts & $\begin{array}{l}\text { Respiratory simple columnar } \\
\text { and pseudocolumnar ciliated } \\
\text { lined cysts }\end{array}$ & $4 \mathrm{~B}, 4 \mathrm{D}$ \\
\hline & Cysts & $\begin{array}{l}\text { Simple columnar mucus cells } \\
\text { lining cysts }\end{array}$ & \\
\hline & Cysts & Simple squamous epithelial cells & $4 \mathrm{~B}, 4 \mathrm{~F}$ \\
\hline & Acini & $\begin{array}{l}\text { Acinar gland-like structures } \\
\& \text { duct-like structures }\end{array}$ & $4 \mathrm{~B}$ \\
\hline
\end{tabular}

showed a hyperechoic mass and an abdominal radiograph showed mineral to bone density material within the $22 \mathrm{~cm}$ mass [36]. Indeed, Patnaik and Greenlee, in a series of 71 primary ovarian tumors in dogs, observed that six of seven teratomas in the series were malignant and that half of those had metastasized [37].

The appearance of the teratoma in this woodchuck was consistent with the description in humans and other small animals. The tumor in this animal was well defined with fat present which is diagnostic for teratoma in humans. The tumor was predominantly solid rather than cystic on imaging but with well-defined calcification suggesting a mature teratoma compared to coarse, illdefined calcification that may be seen in immature teratomas in humans [24]. The diagnosis of teratoma was confirmed at pathology with mature elements representing all three germ layers. Ovarian teratoma should be considered in the differential diagnosis of ovarian or abdominal masses in woodchucks.

\section{Abbreviations}

CT: Computed tomography; MRI: Magnetic resonance imaging; THRIVE: T1weighted High-Resolution Isotropic Volume Examination; DWI: Diffusionweighted imaging; TSE: Turbo Spin Echo; VISTA: Volume Isotropic Turbo Spin Echo Acquisition

\section{Acknowledgements}

This research was made possible through the NIH Medical Research Scholars Program, a public-private partnership supported jointly by the NIH and contributions to the Foundation for the NIH from the Doris Duke Charitable Foundation, Genentech, the American Association for Dental Research, the Colgate-Palmolive Company, and other private donors. These funders had no role in the design or conduct of the study or the preparation, review, or approval of the manuscript.

\section{Authors' contributions}

$\mathrm{MMH}, \mathrm{AM}, \mathrm{AP}, \mathrm{BJW}, \mathrm{JK}$, and WFP conceived of the research under which this subject was studied and contributed to its execution including the conduct and interpretation of the imaging studies. MFS conducted the pathology analysis. JZ, MMH, and WFP reviewed all imaging and pathology information and prepared the manuscript including primary literature review. All authors contributed to manuscript preparation and editing and approved the final version of the manuscript.

\section{Funding}

This work was supported by the Center for Interventional Oncology in the Intramural Research Program of the National Institutes of Health $(\mathrm{NIH})$ by intramural NIH Grants NIH Z01 1ZID BC011242 and CL040015. Dr. MaudaHavakuk is supported by the Intramural Program of the National Institute of Biomedical Imaging and Bioengineering. NIH has a Materials Transfer Agreement with Northeastern Wildlife.

The content of this manuscript does not necessarily reflect the views or policies of the U.S. Department of Health and Human Services. The mention of commercial products, their source, or their use in connection with material reported herein is not to be construed as an actual or implied endorsement of such products by the United States government.

\section{Availability of data and materials}

Our findings are contained within the manuscript.

\section{Ethics approval and consent to participate}

This study was conducted under an animal use protocol approved by the Institutional Animal Care and Use Committee in compliance with the U.S. Animal Welfare Regulations.

\section{Consent for publication}

Not applicable.

\section{Competing interests}

The authors declare that they have no competing interests.

\section{Author details}

${ }^{1}$ Center for Interventional Oncology, Radiology and Imaging Sciences, Clinical Center, National Institutes of Health, 10 Center Drive, Room 3N320, MSC 1182, Bethesda, MD 20892, USA. ²Division of Veterinary Resources, National Institutes of Health, Bethesda, MD 20892, USA. ${ }^{3}$ Center for Interventional Oncology, Radiology and Imaging Sciences, Clinical Center, National Institute of Biomedical Imaging and Bioengineering and National Cancer Institute Center for Cancer Research, National Institutes of Health, Bethesda, MD 20892, USA

Received: 4 May 2020 Accepted: 30 October 2020

Published online: 23 November 2020

\section{References}

1. Meuten DJ. Tumors in domestic animals. Ames, lowa: Wiley; 2017.

2. Meier H, Myers DD, Fox RR, Laird CW. Occurrence, pathological features, and propagation of gonadal teratomas in inbred mice and in rabbits. Cancer Res. 1970;30(1):30-4

3. Tavares IT, Barreno RR, Sales-Luis JP, Vaudano CG. Ovarian teratoma removed by laparoscopic ovariectomy in a dog. J Vet Sci. 2018;19(6):862-4.

4. Sato T, Hontake S, Shibuya H, Shirai W, Yamaguchi T. A solid mature teratoma of a feline ovary. J Feline Med Surg. 2003;5(6):349-51.

5. Williams BH, Yantis LD, Craig SL, Geske RS, Li X, Nye R. Adrenal teratoma in four domestic ferrets (Mustela putorius furo). Vet Pathol. 2001;38(3):328-31.

6. Howerth $B H$, Snyder RL, Miller S. Malignant lymphoma in free-ranging and captive woodchucks. Lab Anim Sci. 1987;37(6):798-800.

7. Nagy T, McDonough SP, Erb HN, Smith CA, Baldwin BH, Tennant BC. Lymphosarcoma in the laboratory woodchuck (Marmota monax). Comp Med. 2002;52(2):152-9.

8. Kang BC, Jang DD, Lee SK. Oral leiomyosarcoma in a woodchuck (Marmota monax). J Vet Med Sci. 2005;67(3):353-5.

9. Young RA, Webster WS. Tumors and polycystic renal disease in two captive woodchucks (Marmota monax). Lab Anim Sci. 1985;35(5):493-6. 
10. Dadone LI, Whiteside DP, Black SR, Remedios A, Raverty S. Nasal osteosarcoma and interstitial cell tumor in a Vancouver Island marmot (Marmota vancouverensis). J Zoo Wildl Med. 2011;42(2):330-4.

11. Kang BC, Lee YS, Lee SK. Malignant pleural mesothelioma in a woodchuck (Marmota monax). J Vet Med Sci. 2004;66(12):1617-9.

12. Podell M, Pokras M, Gerlach $P$, Jakowski R. Meningioma in a woodchuck exhibiting central vestibular deficits. J Wildl Dis. 1988;24(4):695-9.

13. Anderson $\mathrm{WI}$, Johnson RC. Testicular teratoma and seminoma in a woodchuck. Vet Pathol. 1988;25(5):400.

14. Foley GL, Anderson WI, Schlafer DH, Hornbuckle WE, Baldwin BH, Tennant BC. Neoplastic and nonneoplastic lesions of the reproductive tract of the woodchuck (Marmota monax). J Zoo Wildlife Med. 1993;24(4):475-81.

15. Menne S, Cote PJ. The woodchuck as an animal model for pathogenesis and therapy of chronic hepatitis B virus infection. World J Gastroenterol. 2007:13(1):104-24.

16. Roggendorf M, Kosinska AD, Liu J, Lu M. The Woodchuck, a Nonprimate Model for Immunopathogenesis and Therapeutic Immunomodulation in Chronic Hepatitis B Virus Infection. Cold Spring Harb Perspect Med. 2015; 5(12):a021451.

17. Popper H, Roth L, Purcell RH, Tennant BC, Gerin UL. Hepatocarcinogenicity of the woodchuck hepatitis virus. Proc Natl Acad Sci U S A. 1987;84(3):866-70.

18. Tennant BC, Toshkov IA, Peek SF, Jacob JR, Menne S, Hornbuckle WE, et al. Hepatocellular carcinoma in the woodchuck model of hepatitis B virus infection. Gastroenterology. 2004;127(5):S283-S93.

19. Pritchard WF, Woods DL, Esparza-Trujillo JA, Starost MF, Mauda-Havakuk M, Mikhail AS, et al. Transarterial chemoembolization in a woodchuck model of hepatocellular carcinoma. J Vasc Interv Radiol. 2020;31(5):812-9 e1.

20. Fletcher SP, Chin DJ, Gruenbaum L, Bitter H, Rasmussen E, Ravindran P, et al. Intrahepatic transcriptional signature associated with response to interferonalpha treatment in the woodchuck model of chronic hepatitis B. PLoS Pathog. 2015;11(9):e1005103.

21. Mikhail AS, Mauda-Havakuk M, Partanen A, Karanian JW, Pritchard WF, Wood BJ. Liver-specific 3D sectioning molds for correlating in vivo CT and MRI with tumor histopathology in woodchucks (Marmota monax). PLoS One. 2020;15(3):e0230794

22. Buy JN, Ghossain MA, Moss AA, Bazot M, Doucet M, Hugol D, et al. Cystic teratoma of the ovary: CT detection. Radiology. 1989;171(3):697-701.

23. Quillin S, Siegel MJ. CT features of benign and malignant teratomas in children. J Comput Assist Tomogr. 1992;16(5):722-6.

24. Pereira JM, Sirlin CB, Pinto PS, Casola G. CT and MR imaging of extrahepatic fatty masses of the abdomen and pelvis: techniques, diagnosis, differential diagnosis, and pitfalls. Radiographics. 2005;25(1):69-85.

25. Miyazaki T, Fukui M, Inagaki E, Miki K, Takabayashi S, Katoh H, et al. Identification of two additional genomic loci responsible for experimentally induced testicular teratoma 2 and 3 (ett2 and ett3). Zool Sci. 2018;35(2):172-8.

26. Langer B, Dorsch M, Gartner K, Wedekind D, Kamino K, Hedrich HJ. WKY Ztm-ter: a new rat inbred strain on the WKY/Ztm genetic background with congenital teratomas. Lab Anim. 2004;38(4):425-31.

27. Northrup E, Zschemisch NH, Eisenblatter R, Glage S, Wedekind D, Cuppen E, et al. The ter mutation in the rat Dnd1 gene initiates gonadal teratomas and infertility in both genders. PLoS One. 2012;7(5):e38001.

28. Riegler J, Ebert A, Qin X, Shen Q, Wang M, Ameen M, et al. Comparison of magnetic resonance imaging and serum biomarkers for detection of human pluripotent stem cell-derived Teratomas. Stem Cell Reports. 2016; 6(2):176-87.

29. Beregi A, Molnar V, Perge E, Felkai C. Radiography and ultrasonography in the diagnosis and treatment of abdominal enlargements in five Guinea pigs. J Small Anim Pract. 2001;42(9):459-63.

30. Basaraba RJ, Kraft SL, Andrews GA, Leipold HW, Small D. An ovarian teratoma in a cat. Vet Pathol. 1998;35(2):141-4

31. Dehner LP, Norris HJ, Garner FM, Taylor HB. Comparative pathology of ovarian neoplasms. 3. Germ cell tumours of canine, bovine, feline, rodent and human species. J Comp Pathol. 1970;80(2):299-306.

32. Nagashima Y, Hoshi K, Tanaka R, Shibazaki A, Fujiwara K, Konno K, et al. Ovarian and retroperitoneal teratomas in a dog. J Vet Med Sci. 2000; 62(7):793-5.

33. Tappin S, Norman D. What is your diagnosis? Ovarian teratoma. J Small Anim Pract. 2007:48(1):53-5.

34. Lopez D, Singh A, Wright TF, Gartley C, Walker M. Single incision laparoscopic-assisted ovariohysterectomy for an ovarian tumor in a dog. Can Vet J. 2017;58(9):975-9.
35. Headley SA, Fuck EJ, Fuck ET, Curti CE. Ovarian teratoma in a bitch. Vet Rec. 2006;158(16):565-7.

36. Gorman ME, Bildfell $R$, Seguin B. What is your diagnosis? Peritoneal fluid from a 1-year-old female German shepherd dog. Vet Clin Pathol. 2010;39(3):393-4.

37. Patnaik AK, Greenlee PG. Canine ovarian neoplasms: a clinicopathologic study of 71 cases, including histology of 12 granulosa cell tumors. Vet Pathol. 1987;24(6):509-14.

\section{Publisher's Note}

Springer Nature remains neutral with regard to jurisdictional claims in published maps and institutional affiliations.

\section{Ready to submit your research? Choose BMC and benefit from:}

- fast, convenient online submission

- thorough peer review by experienced researchers in your field

- rapid publication on acceptance

- support for research data, including large and complex data types

- gold Open Access which fosters wider collaboration and increased citations

- maximum visibility for your research: over $100 \mathrm{M}$ website views per year

At $\mathrm{BMC}$, research is always in progress.

Learn more biomedcentral.com/submissions 